\title{
Hepatoprotective Effect of Andrographis paniculata against Oxidative Damage Caused by Cisplatin in Rats
}

\author{
T. Rajendrakumar ${ }^{1 *}$, Suguna Rao ${ }^{1}$, M. L. Satyanarayana ${ }^{1}$, H. D. Narayanaswamy ${ }^{1}$, \\ S. M. Byregowda ${ }^{2}$ and N. B. Shridhar ${ }^{3}$
}

${ }^{1}$ Department of Veterinary Pathology, Veterinary College, KVAFSU, Hebbal, Bangalore-560024, India ${ }^{2}$ Institute of Animal Health and Veterinary Biologicals, KVAFSU, Bangalore, India

${ }^{3}$ Asscociate Professor, Department of Veterinary Pharmacology, Veterinary College, Vinobanagar, Shimogga-577204, India

*Corresponding author

\section{A B S T R A C T}

\begin{tabular}{|l|}
\hline Keyw or d s \\
Cisplatin, \\
antioxidants, \\
hepatotoxicity, \\
Andrographis \\
paniculata, \\
Malondialdehyde \\
\hline Article Info \\
\hline $\begin{array}{l}\text { Accepted: } \\
\text { 08 January 2020 } \\
\text { Available Online: } \\
\text { 10 February } 2020\end{array}$ \\
\hline \hline
\end{tabular}

The role of ethanolic extract of Andrographis paniculata (AP), in preventing cisplatin (CP) induced oxidative damage in rat liver was studied. The study included 60 Wistar albino rats were divided into 12 rats in each group. Group I served as normal control group. To group II rats, CP was administered at $7.5 \mathrm{mg} / \mathrm{kg}$ body weight intraperitoneally for single dose. Rats in group III were administered AP at the dose of $500 \mathrm{mg} / \mathrm{kg}$ body weight for 45 days. Group IV rats were pre-treated with AP 15 days prior to $\mathrm{CP}$ administration and followed by AP treatment for 45 days. Rats in group $\mathrm{V}$ were administered with $\mathrm{CP}$ and concurrently treated with AP extract at $500 \mathrm{mg} / \mathrm{kg}$ by oral gavaging for 45 days. The liver samples collected at $7^{\text {th }}, 14^{\text {th }}, 28^{\text {th }}$, and $45^{\text {th }}$ day of the study were subjected for estimation of endogenous antioxidant enzymes (SOD, CAT and GPx) and malondialdehyde (MDA). Significant decrease $(\mathrm{P}<0.05)$ in the levels of antioxidant enzymes and increase in MDA levels were recorded in CP treatment group. The AP treatment groups revealed a significant recovery $(\mathrm{P}<0.05)$ all enzymes and decrease in MDA levels which suggested that AP has a good antioxidant effect and could be effectively used for prevention of toxic side effects of CP.

\section{Introduction}

Cisplatin is a platinum-based alkylating antineoplastic agent and used as the backbone of myriad treatment regimens across a broad spectrum of malignancies (Crona et al.,
2017). Among the anti-tumor drugs, cisplatin occupies a very important place, as its therapeutic efficacy for certain cancer types is remarkably high. Cisplatin-based blended chemotherapy regimens are presently used as a significant therapy in the treatment of 
testicular cancer, ovarian germ cell tumors, epithelial ovarian cancer, head and neck cancer, advanced cervical cancer, bladder cancer, mesothelioma, endometrial cancer, non-small cell lung cancer, malignant melanoma, carcinoids, penile cancer, adrenocortical carcinoma etc. in humans (Hill and Speer, 1982 and Galanski, 2006).

The toxic effects of cisplatin are due to its close interaction with DNA molecules. Cisplatin thus arrests DNA synthesis and replication in rapidly proliferating cells (Rastogi et al., 2014). Cisplatin does not distinguish between a malignant and normal fast-growing cell, hence, eliminates both type of cells by exerting several toxicities as its side effects such as nephrotoxicity, hepatotoxicity, cardiotoxicity, gastrotoxicity, ototoxicity, neurotoxicity, myelosuppression and thrombocytopenia (Dasari and Tchounwou, 2014).

Hepatotoxicity is one of the major side effects of cisplatin produced at high doses (Kim et al., 2004). The exact mechanism of cisplatin induced hepatotoxicity is not known, however oxidative stress induced by cisplatin might be one of the causes. Along with interaction with DNA, the oxidative stress that occurs during biotransformation of the drug is also one of the most important mechanisms involved in cisplatin-induced toxicity resulting in the enhanced production of reactive oxygen species, reduction in the mitochondrial membrane potential and decrease in antioxidant enzymes (Saad et al., 2004).

Cisplatin induces oxidative stress in liver by enhancing the production of reactive oxygen species (ROS), like superoxide, hydrogen peroxide, hydroxyl ions and oxygen free radicals and nitrogen reactive species (NRS). The imbalance between formation of ROS and RNS in metabolism leads to pathological consequences in the liver (Yilmaz et al.,
2005). Since long time, alleviation of cisplatin induced toxicity has been the prime concern during therapeutic intervention with cisplatin.

There is an increasing interest in the use of phytochemicals, medicinal plants and their formulations for evaluating their efficacy in combination with chemotherapeutic agents in traditional system of medicine and in ethanomedical practices to prevent toxic effects of chemotherapeutic agents (Singh and Aggarwal, 2006). Many antioxidants, herbal plants and phytochemical compounds have been studied as protective agents to scavenge free radicals formed by exposure to cisplatin (Abdelmeguid et al., 2010).

Andrographis paniculata is one such important medicinal plant widely used around the world. It belongs to the family Acanthaceae and most commonly used in the traditional systems of Unani and Ayurvedic medicines and is considered as "king of bitters". It is an annual plant, It grows in hedge rows throughout the plains of India and is also cultivated in gardens (Hossain et al., 2014).

Phytochemical analyses of Andrographis paniculata have revealed that it is a rich source of diterpenoids, andrographolide, neoandrographolide, 14-deoxyandrographolide, iso-andrographolide, $\quad 14-\beta$-deoxyandrographolide, 19- $\beta$-glucoside, homoandrographolide, andrographan, andrographosterin, and stigmasterol.

Andrographolide is the primary bioactive phytochemical of Andrographis paniculata and it exhibits significant anti-oxidant, antiinflammatory and has chemo-protective potential towards normal cells (Bardi et al., 2014). The present study aimed to investigate the possible protective effect of Andrographis paniculata on antioxidant enzymes and lipid peroxidation. 


\section{Materials and Methods}

\section{Drugs and chemicals}

Cisplatin (Kemoplat) was procured from Fresenius Kabi India Pvt. Ltd. Pune, India. and the ethanolic extract of Andrographis paniculata was obtained from Himalaya Herbal Pvt Ltd. Bangalore, India

\section{Animals}

Normal adult Wistar albino rats weighing approximately 180-200 grams were procured from commercial animal facility, Bangalore for the study. They were maintained under standard laboratory conditions and fed with ad libitum standard commercial rat feed and clean drinking water. The duration of experiment was for a period of 45 days and a prior permission was obtained from the Institutional Animal Ethics Committee (IAEC) for the conduct of the experiment.

\section{Experimental design}

The rats were maintained under standard laboratory conditions for a period of 15 days for acclimatization in the experimental animal house. The rats were divided, based on the body weight, into five groups with twelve rats in each group. Group I was kept as normal control and injected with $0.5 \mathrm{ml}$ sterile PBS intraperitoneally on Day 1 and gavaged with PBS daily. Group II was positive control and hepatotoxicity induced with administration of cisplatin at $7.5 \mathrm{mg} / \mathrm{kgbody}$ weight intraperitoneally for single dose.

Group III was supplemented with ethanolic extract of Andrographis paniculata alone at the dose rate of $500 \mathrm{mg} / \mathrm{kg}$ body weight. Group IV was supplemented with Andrographis paniculata extract at the dose rate of $500 \mathrm{mg} / \mathrm{kg}$ bodyweight 15 days prior to induction of hepatotoxicity by CP. Group V was supplemented with Andrographis paniculata extract at the dose rate of $500 \mathrm{mg} / \mathrm{kg}$ body weight concurrently with administration of $\mathrm{CP}$.

\section{Collection of liver samples}

To study the progressive effects of the treatments given to different groups, rats from each group were sacrificed humanely under ketamine hydrochloride on $7^{\text {th }}, 14^{\text {th }}, 28^{\text {th }}$, and $45^{\text {th }}$ day of the experiment. Liver from all the group of animals were collected in chilled normal saline and then transferred to $-80^{\circ} \mathrm{C}$ for further analysis.

\section{Estimation of superoxide dismutase (SOD)}

Superoxide dismutase activity was determined by the method described by Marklund and Marklund(1974). The enzyme activity was expressed in terms of units per minute per mg of protein. One unit of SOD was defined as the amount of enzyme required to inhibit pyrogallol auto-oxidation reaction by 50 percent.

\section{Estimation of catalase (CAT)}

Catalase was estimated by the method described by Caliborne (1985).Enzyme activity was expressed as $\mu \mathrm{mol}$ of $\mathrm{H}_{2} \mathrm{O}_{2}$ decomposed per minute per $\mathrm{mg}$ of protein.

\section{Estimation of glutathione peroxidase (GPx)}

Glutathione peroxidase was determined by themethod described by Rotruck et al., (1973). Enzymeactivity was expressed as units per mg protein.

\section{Estimation of TBARS (Malondialdehyde):}

Lipid peroxidation in the liver tissue was determined by estimation of thiobarbituric acid reactive substance (TBARS) by the 
method of Yagi (1976). The unit of activity was expressed as $\mathrm{n}$ moles of MDA /mg of tissue.

\section{Results and Discussion}

The effect of CP administration on the antioxidant enzyme status and lipid peroxidation in liver of rats was analyzed. The results indicated that $\mathrm{CP}$ caused a significant decrease $[\mathrm{P}<0.05]$ in the levels of SOD, CAT and GPx (Tables 1,2,3 and Figure $1,2,3)$ and significant increase $[\mathrm{P}<0.05]$ in the level of MDA (Table 4 and Figure 4) in Group- II when compared to other groups, throughout the duration of the experiment.

These findings indicated that cisplatin treatment can induce liver damage through oxidative stress. Under normal physiological conditions, cells control reactive oxygen species levels by balancing the generation of reactive oxygen species with their elimination by scavenging system. But under oxidative stress conditions, excessive reactive oxygen species generated can damage cellular proteins, lipids and DNA, leading to fatal lesions in cells.

Oxidative stress is one important mechanism involved in the cisplatin hepatotoxicity. The mitochondria are the primary target in cisplatin toxicity with loss of mitochondrial protein sulfhydryl group and reduction in the mitochondrial membrane potential (Saad et al., 2004). Mitochondrial glutathione (GSH) is essential in the regulation of inner mitochondrial permeability and enzyme function by keeping $\mathrm{SH}$ in the reduced state. In cisplatin induced toxicity, there is an increase in the intracellular calcium level which activates NADPH oxidase and ROS production by damaged mitochondria (Yao et al., 2007). GSH is one of the most important molecules in the cellular defense against chemically reactive toxic compounds. The reduced form of GSH is necessary for detoxification of xenobiotics. The reduction in GSH levels induced by cisplatin causes suppression of antioxidant enzyme defense system sensitizing the cells to ROS, thus causing hepatic injury (Mansour et al., 2006; Nasr, 2014 and Ciftci et al., 2017).

Nicotinamide adenine dinucleotide (NADH), which helps to maintain $\mathrm{SH}$ groups, declines with cisplatin treatment resulting in the inhibition of some dehydrogenases, which cause uncoupling of oxidative phosphorylation with formation hydroxyl radical and oxidative stress. These free radicals attack polyunsaturated lipids and proteins and initiate lipid peroxidation. (Aggarwal, 1998 and Yilmaz, et al., 2005).

The drug is also involved in the alteration of the thiol status of tissue resulting in the alteration in the enzymatic antioxidants. The intracellular redox homeostasis is maintained by the thiol group (-SH) containing molecules. Under certain conditions, thiol group may lead to formation of thiol radicals that in turn interacts with molecular oxygen, generating reactive oxygen species (Desoize, 2002).

The antioxidants play an important role in protection against damage caused by reactive oxygen species (ROS). Reduction in the antioxidant enzyme levels in the current study could be attributed to their utilization in elimination of excess of reactive oxygen species generated during cisplatin toxicity. Bilgic et al., (2018) indicated that in CP induced hepatotoxicity, liver cells encounter large quantities of ROS which overwhelm their detoxification capacity and succumb to toxic effects with depletion of antioxidants. Under normal conditions, protection against ROS is by utilization of NADPH by glutathione reductase to maintain the reduced state of cellular glutathione which is an 
important cytosolic antioxidant.

The observations of the study concurred with previous studies which have demonstrated involvement of oxidative stress, lipid peroxidation and mitochondrial dysfunction in cisplatin induced hepatotoxicity (Mansour et al., 2006; Fasihi et al., 2012; Karale and Kamath, 2016 and Ciftci et al., 2017).

Administration of ethanolic extract of Andrographis paniculata ameliorated the deleterious effects of $\mathrm{CP}$ which was reflected by significant recovery $(\mathrm{P}<0.05)$ in the levels of SOD, GPx and CAT in the animals of Group-IV and Group-V (Tables 1,2,3 and Figure 1, 2, 3) and also by significant reduction $(\mathrm{P}<0.05)$ in the levels of MDA (Table 4 and Figure 4). Improvement in the levels of antioxidants $[\mathrm{P}<0.05]$ and $\mathrm{MDA}$ $(\mathrm{P}<0.05)$ was significant in the AP pretreated group [Group-IV] when compared to concurrent AP treatment group [Group-V]. These finding indicating the protective and antioxidant effect of AP against $\mathrm{CP}$ which could be attributable to presence of phytochemicals like diterpenoids, flavonoids, tannins, saponins and andrographolides (Verma et al., 2019). The inhibitory effect of Andrographis paniculata on chemically induced cytotoxicity, lipid peroxidation and oxidative stress has been reported in $\mathrm{CCl}_{4}$, benzene hexachloride, paracetamol, and galactosamine induced hepatic damage (Akbar, 2011). The hepatoprotective effect of diterpenes of Andrographis paniculata have been attributed to prevention of oxidation, inhibition of P450 enzymes, stimulation of hepatic regeneration and inhibition of microsomal enzymes and lipid peroxidation (Verma et al., 2019).

The results of the current study suggest that single dose of cisplatin at $7.5 \mathrm{mg} / \mathrm{kg}$ intraperitoneally induces oxidative stress in Wistar albino rats by decreasing the cellular endogenous antioxidants enzymes thereby increases the MDA levels and Andrographis paniculata can ameliorate the toxic effects of cisplatin in rats and pretreatment of AP is more effective in comparison with concurrent treatment.

Table.1 The mean $( \pm \mathrm{SE})$ values of superoxide dismutase (SOD) levels (U/min/mg protein) in liver of rats in different groups at different time intervals.

\begin{tabular}{|c|c|c|c|c|}
\hline \multirow{2}{*}{ Groups } & \multicolumn{3}{|c|}{ Days post treatment } \\
\cline { 2 - 5 } & $07^{\text {th }}$ & $14^{\text {th }}$ & $28^{\text {th }}$ & $45^{\text {th }}$ \\
\hline $\begin{array}{c}\text { Group-I } \\
\text { Negative control }\end{array}$ & $28.32 \pm 0.05^{\mathrm{ax}}$ & $29.35 \pm 0.04^{\mathrm{ax}}$ & $30.70 \pm 0.15^{\mathrm{ay}}$ & $31.60 \pm 0.42^{\mathrm{az}}$ \\
\hline $\begin{array}{c}\text { Group-II } \\
\text { CP control }\end{array}$ & $9.57 \pm 0.13^{\mathrm{bx}}$ & $13.57 \pm 0.13^{\mathrm{by}}$ & $14.74 \pm 0.04^{\mathrm{bz}}$ & $16.03 \pm 0.23^{\mathrm{bw}}$ \\
\hline $\begin{array}{c}\text { Group-III } \\
\text { AP Control }\end{array}$ & $31.60 \pm 0.15^{\mathrm{ax}}$ & $30.90 \pm 0.04^{\mathrm{ax}}$ & $31.94 \pm 0.03^{\mathrm{ax}}$ & $33.90 \pm 0.08^{\mathrm{ay}}$ \\
\hline $\begin{array}{c}\text { Group-IV } \\
\text { AP pre-treatment group }\end{array}$ & $19.96 \pm 0.03^{\mathrm{cx}}$ & $21.82 \pm 0.05^{\mathrm{cy}}$ & $23.94 \pm 0.03^{\mathrm{cz}}$ & $24.86 \pm 0.25^{\mathrm{cw}}$ \\
\hline $\begin{array}{c}\text { Group-V } \\
\text { AP concurrent group }\end{array}$ & $13.06 \pm 0.01^{\mathrm{dx}}$ & $14.36 \pm 0.08^{\mathrm{dy}}$ & $20.27 \pm 0.01^{\mathrm{dz}}$ & $20.83 \pm 0.08^{\mathrm{dz}}$ \\
\hline
\end{tabular}

Values with different superscripts in a row and column vary significantly at $\mathrm{p}<0.05$ 
Table.2 The mean $( \pm \mathrm{SE})$ values of catalase $(\mu \mathrm{mol} / \mathrm{min} / \mathrm{mg}$ protein $)$ levels in liver of rats in different groups at different time intervals

\begin{tabular}{|c|c|c|c|c|}
\hline \multirow{2}{*}{ Groups } & \multicolumn{3}{|c|}{ Days post treatment } \\
\cline { 2 - 5 } & $07^{\text {th }}$ & $14^{\text {th }}$ & $28^{\text {th }}$ & $45^{\text {th }}$ \\
\hline $\begin{array}{c}\text { Group-I } \\
\text { Negative control }\end{array}$ & $50.79 \pm 0.139^{\mathrm{ax}}$ & $49.52 \pm 0.22^{\mathrm{ay}}$ & $52.81 \pm 0.17^{\mathrm{az}}$ & $52.37 \pm 0.30^{\mathrm{az}}$ \\
\hline $\begin{array}{c}\text { Group-II } \\
\text { CP control }\end{array}$ & $26.57 \pm 0.115^{\mathrm{bx}}$ & $26.05 \pm 0.1^{\mathrm{bx}}$ & $27.84 \pm 0.07^{\mathrm{by}}$ & $30.19 \pm 0.50^{\mathrm{bz}}$ \\
\hline $\begin{array}{c}\text { Group-III } \\
\text { AP Control }\end{array}$ & $51.77 \pm 0.09^{\mathrm{ax}}$ & $50.02 \pm 0.23^{\mathrm{ay}}$ & $50.44 \pm 0.01^{\mathrm{ay}}$ & $53.13 \pm 0.11^{\mathrm{az}}$ \\
\hline $\begin{array}{c}\text { Group-IV } \\
\text { AP pre-treatment group }\end{array}$ & $39.09 \pm 0.24^{\mathrm{cx}}$ & $40.38 \pm 0.04^{\mathrm{cy}}$ & $42.40 \pm 0.05^{\mathrm{cz}}$ & $44.76 \pm 0.19^{\mathrm{cw}}$ \\
\hline $\begin{array}{c}\text { Group-V } \\
\text { AP concurrent group }\end{array}$ & $30.99 \pm 0.03^{\mathrm{dx}}$ & $32.49 \pm 0.04^{\mathrm{dy}}$ & $33.09 \pm 0.04^{\mathrm{dz}}$ & $36.36 \pm 0.62^{\mathrm{dw}}$ \\
\hline
\end{tabular}

Values with different superscripts in a row and column vary significantly at $\mathrm{p}<0.05$

Table.3 The mean $( \pm \mathrm{SE})$ values of glutathione peroxidase (GPx) levels (U/mg protein) in liver of rats in different groups at different time intervals

\begin{tabular}{|c|c|c|c|c|}
\hline \multirow{2}{*}{ Groups } & \multicolumn{3}{|c|}{ Days of post treatment } \\
\cline { 2 - 5 } & $07^{\mathrm{th}}$ & $14^{\mathrm{th}}$ & $28^{\mathrm{th}}$ & $45^{\mathrm{th}}$ \\
\hline $\begin{array}{c}\text { Group-I } \\
\text { Negative control }\end{array}$ & $32.155 \pm 0.25^{\mathrm{ax}}$ & $30.89 \pm 0.08^{\mathrm{ay}}$ & $32.915 \pm 0.16^{\mathrm{ax}}$ & $33.96 \pm 0.06^{\mathrm{ax}}$ \\
$\begin{array}{c}\text { Group-II } \\
\text { CP control }\end{array}$ & $10.78 \pm 0.06^{\mathrm{bx}}$ & $12.93 \pm 0.03^{\mathrm{by}}$ & $15.5 \pm 0.1^{\mathrm{bz}}$ & $15.88 \pm 0.16^{\mathrm{bz}}$ \\
\hline $\begin{array}{c}\text { Group-III } \\
\text { AP Control }\end{array}$ & $32.96 \pm 0.15^{\mathrm{ax}}$ & $32.61 \pm 0.07^{\mathrm{ax}}$ & $33.93 \pm 0.05^{\mathrm{ay}}$ & $34.47 \pm 0.18^{\mathrm{az}}$ \\
\hline $\begin{array}{c}\text { Group-IV } \\
\text { AP pre-treatment group }\end{array}$ & $25.96 \pm 0.06^{\mathrm{cx}}$ & $26.92 \pm 0.02^{\mathrm{cy}}$ & $27.69 \pm 0.03^{\mathrm{cz}}$ & $28.79 \pm 0.20^{\mathrm{cw}}$ \\
\hline $\begin{array}{c}\text { Group-V } \\
\text { AP concurrent group }\end{array}$ & $15.58 \pm 0.014^{\mathrm{dx}}$ & $16.79 \pm 0.05^{\mathrm{dy}}$ & $20.315 \pm 0.06^{\mathrm{dz}}$ & $22.14 \pm .07^{\mathrm{dw}}$ \\
\hline
\end{tabular}

Values with different superscripts in a row and column vary significantly at $\mathrm{p}<0.05$

Table.4 The mean ( \pm SE) values of malondialdehyde (MDA) levels (n moles/mg tissue) in liver of rats in different groups at different time intervals

\begin{tabular}{|c|c|c|c|c|}
\hline \multirow{2}{*}{ Groups } & \multicolumn{3}{|c|}{ Days post treatment } \\
\cline { 2 - 5 } & $07^{\text {th }}$ & $14^{\text {th }}$ & $28^{\text {th }}$ & $45^{\text {th }}$ \\
\hline $\begin{array}{c}\text { Group-I } \\
\text { Negative control }\end{array}$ & $0.98 \pm 0.03^{\mathrm{ax}}$ & $1.045 \pm 0.04^{\mathrm{ax}}$ & $1.025 \pm 0.014^{\mathrm{ax}}$ & $1.00 \pm 0.02^{\mathrm{ax}}$ \\
\hline $\begin{array}{c}\text { Group-II } \\
\text { CP control }\end{array}$ & $3.595 \pm 0.07^{\mathrm{bx}}$ & $4.885 \pm 0.06^{\mathrm{by}}$ & $5.86 \pm 0.06^{\mathrm{bz}}$ & $4.6 \pm 0.17^{\mathrm{bw}}$ \\
\hline $\begin{array}{c}\text { Group-III } \\
\text { AP Control }\end{array}$ & $0.91 \pm 0.03^{\mathrm{ax}}$ & $0.9375 \pm 0.02^{\mathrm{ax}}$ & $1.021 \pm 0.02^{\mathrm{ay}}$ & $0.939 \pm 0.04^{\mathrm{ax}}$ \\
\hline $\begin{array}{c}\text { Group-IV } \\
\text { AP pre-treatment group }\end{array}$ & $3.0 \pm 0.01^{\mathrm{cx}}$ & $3.72 \pm 0.04^{\mathrm{cy}}$ & $3.285 \pm 0.01^{\mathrm{cy}}$ & $2.47 \pm 0.19^{\mathrm{cz}}$ \\
\hline $\begin{array}{c}\text { Group-V } \\
\text { AP concurrent group }\end{array}$ & $3.16 \pm 0.09^{\mathrm{cx}}$ & $4.05 \pm 0.03^{\mathrm{cy}}$ & $3.57 \pm 0.01^{\mathrm{dx}}$ & $3.11 \pm 0.06^{\mathrm{dx}}$ \\
\hline
\end{tabular}

Values with different superscripts in a row and column vary significantly at $\mathrm{p}<0.05$ 


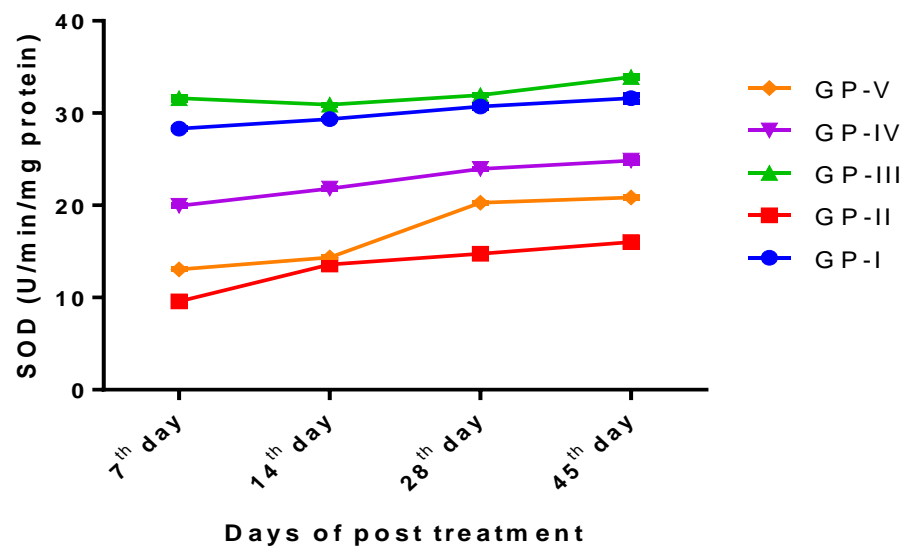

Figure.1 The mean $( \pm \mathrm{SE}$ ) values of superoxide dismutase (SOD) levels (U/min/mg protein) in liver of rats in different groups at different time intervals

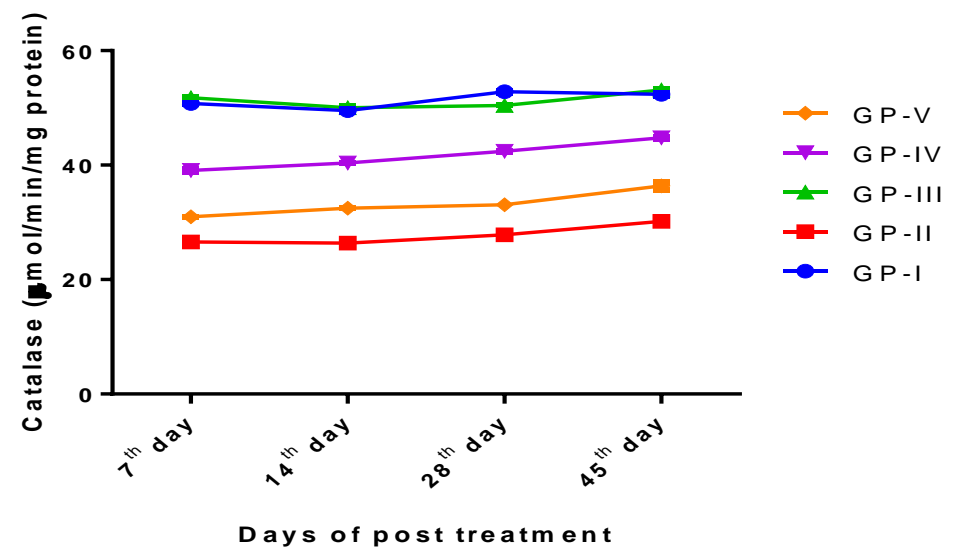

Figure.2 The mean $( \pm \mathrm{SE})$ values of catalase $(\mu \mathrm{mol} / \mathrm{min} / \mathrm{mg}$ protein) levels in liver of rats in different groups at different time intervals

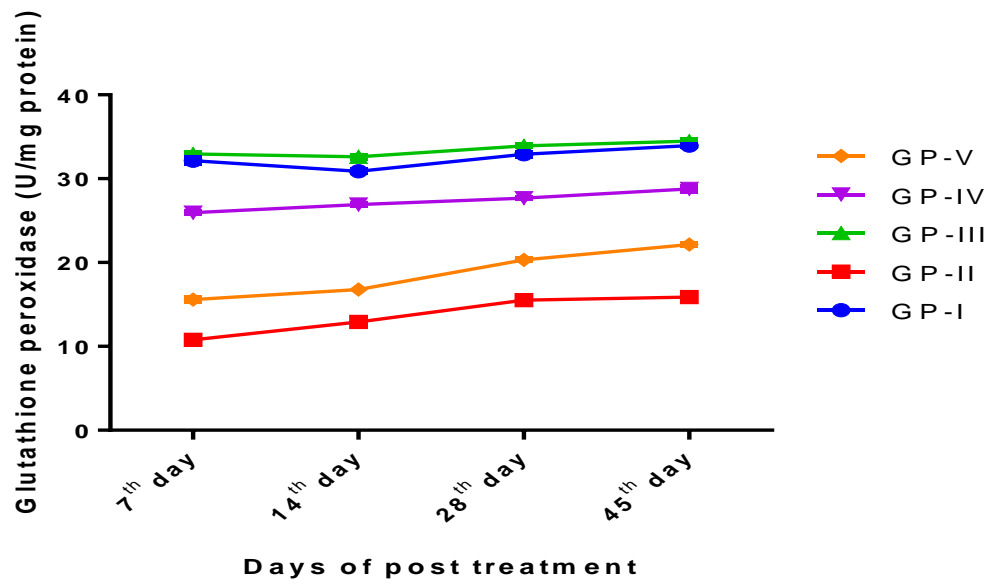

Figure.3 The mean $( \pm \mathrm{SE})$ values of glutathione peroxidase (GPx) levels (U/mg protein) in liver of rats in different groups at different time intervals 


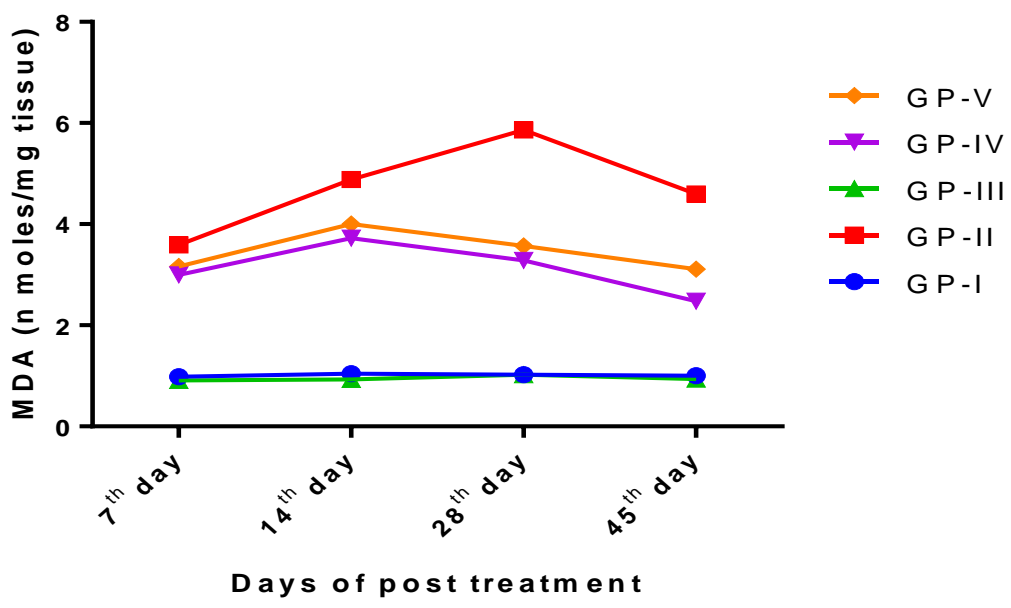

Figure.4 The mean $( \pm \mathrm{SE})$ values of malondialdehyde (MDA) levels (n moles/mg tissue) in liver of rats in different groups at different time intervals

\section{Acknowledgements}

Authors are thankful to the Head of the Department, Department of Veterinary pathology and Dean, Veterinary College, Bangalore, for providing facilities to carry out the present study.

\section{References}

Abdelmeguid, N.E., Chmaisse, H.N. and Zeinab, N.A., 2010. Silymarin ameliorates cisplatin-induced hepatotoxicity in rats: histopathological and ultrastructural studies. Pak. J. Biol. Sci., 13(10): 463.

Aggarwal, S., K. 1998. Calcium modulation of toxicities due to Cisplatin. Metalbased drugs. 5: 77-81.

Akbar, S. 2011. Andrographis paniculata: A review of pharmacological activities and clinical effects, Altern. Med. Rev., 16(1): 66-77.

Bardi, D. A, Halabi, M. F, Hassandarvish, P., Rouhollahi, E. and Paydar, M. 2014. Andrographis paniculata leaf extract prevents thioacetamide-induced liver cirrhosis in rats. Plos One., 9(10): 1-13.
Bilgic, Y., Akbulut, S., Aksungur, Z., Erdemli, M.E., Ozhan, O., Parlakpinar, H., Vardi, N. and Turkoz, Y., 2018. Protective effect of dexpanthenol against cisplatin-induced hepatotoxicity. Exp. Ther. Medicine, 16(5): 4049-4057.

Caliborne, A.L., 1985. Assay of catalase: Handbook of oxygen radical research. Ed. Greenward, R.A., CRC Press.

Ciftci, O., Onat, E. and Cetin, A., 2017. The beneficial effects of fish oil following cisplatin-induced oxidative and histological damage in liver of rats. Ira. J. Pharm. Res., 16(4): 1424-1431.

Crona, D.J., Faso, A., Nishijima, T.F., Mcgraw, K.A., Galsky, M.D. and Milowsky, M.I., 2017. A systematic review of strategies to prevent cisplatin- induced nephrotoxicity. Oncol., 22(5): 609-619.

Dasari, S. and Tchounwou, P.B., 2014. Cisplatin in cancer therapy: Molecular mechanisms of action. Eur. J. Pharmacol., 740: 364-378.

Desoize, B., 2002. Cancer and metals and metal compounds: part I-carcinogenesis. Crit. Rev. Oncol. Hematol., 42(1): 1. 
Fasihi, M., Ghodratizadeh, M. and Ghodratizadeh, S., 2012. Protective effect of captopril on cisplatin induced hepatotoxicity in rat. AmericanEurasian J Toxicol Sci, 4: 131-134 .

Galanski, M., 2006. Recent developments in the field of anticancer platinum complexes. Recent patents on anticancer drug discovery, 1(2): 285-295.

Hill, J.M. and Speer, R.J., 1982. Organoplatinum complexes as anti-tumor agents. Anticancer Res., 2(3): 173-186.

Hossain, M. D., ZannatUrbi, Abubakar Sule, and Hafizur Rahman. 2014. Andrographis paniculata (Burm. f.) Wall. ex Nees: A Review of Ethnobotany, Phytochemistry, and Pharmacology. Sci. World J., 2014:128.

Karale, S. and Kamath, J.V., 2017. Effect of daidzein on cisplatin-induced hematotoxicity and hepatotoxicity in experimental rats. Indian J. Pharmacol., 49(1): 49-54.

Kim, S.H., Hong, K.O., Chung, W.Y., Hwang, J.K. and Park, K.K., 2004. Abrogation of cisplatin-induced hepatotoxicity in mice by xanthorrhizol is related to its effect on the regulation of gene transcription. Toxicol. Appl. Pharmacol., 196(3): 346-355.

Mansour, H.H., Hafez, H.F. and Fahmy, N.M., 2006. Silymarin modulates cisplatin-induced oxidative stress and hepatotoxicity in rats. Biochem Mol Biol J., 39(6): 656-661.

Marklund, S and marklund, G., 1974. Involvement of the Superoxide Anion Radical in the Autoxidation of Pyrogallol and a Convenient Assay for Superoxide Dismutase. Eur. J. Biochem., 47: 469-474.

Nasr, A.Y., 2014. Protective effect of aged garlic extract against the oxidative stress induced by cisplatin on blood cells parameters and hepatic antioxidant enzymes in rats. Toxicol. Repo., 1: 682691.

Rastogi, S.S., Singh, M., Kumar, M., Mishra, A. and Shrestha, U. 2014. Hepatoprotective Action of Andrographis paniculata Against Cisplatin Induced Toxicity in Mice: A Histological Study. Res. J. Phar. Biol. Chem. Sci.,5(4): 1242-1250.

Rotruck, J.T., Pope, A.L., Ganther, H.E., Swanson, A.B., Hafeman, D.G. and Hockstra, W.G., 1973. Selenium: Biochemical role as a component of glutathione peroxidase. Science., 179: 588-598.

Saad, S.Y., Najjar, T.A. and Alashari, M., 2004. Role of non- selective adenosine receptor blockade and phosphodiesterase inhibition in cisplatin- induced nephrogonadal toxicity in rats. Clin. Exp. Pharmacol. Physiol., 31(12): 862-867.

Singh, R. P and Agarwal, R. 2006. Natural flavonoids targeting deregulated cell cycle progression in cancer cells. Current drug targets., 7(3):345-354.

Verma, H. Negi., M.S., Mahapatra, B.S. Anil shukla and Jaipaul. 2019. Evaluation of an emerging medicinal crop Kalmegh[Andrographis paniculate (Burm. F.) Wall. Ex. Nees] for commercial cultivation and pharmaceutical \& industrial uses: a review. Pharmacogn., 8(4): 835-848.

Yagi, 1976. A simple fluorometric assay for lipoperoxide in blood plasma. Biochem. Med., 15: 212-216.

Yao, X., Panichpisal, K., Kurtzman, N. and Nugent, K., 2007. Cisplatin nephrotoxicity: a review. Am. J. Med. Sci., 334(2):115-124.

Yilmaz, H.R., Sogut, S., Ozyurt, B., Ozugurlu, F., Sahin, S., Isik, B., Uz, E. and Ozyurt, H., 2005. The activities of liver adenosine deaminase, xanthine oxidase, catalase, superoxide dismutase 
enzymes and the levels of malondialdehyde and nitric oxide after cisplatin toxicity in rats: protective

effect of caffeic acid phenethyl ester. Toxicol. Indl. Health, 21(1-2): 67-73.

\section{How to cite this article:}

Rajendrakumar. T., Suguna Rao, M. L. Satyanarayana, H. D. Narayanaswamy, S. M. Byregowda and Shridhar. N.B. 2020. Hepatoprotective Effect of Andrographis paniculata against Oxidative Damage Caused by Cisplatin in Rats. Int.J.Curr.Microbiol.App.Sci. 9(02): 1001-1010. doi: https://doi.org/10.20546/ijcmas.2020.902.117 